\title{
Superficial Cervical Lymph Node
}

National Cancer Institute

\section{Source}

National Cancer Institute. Superficial Cervical Lymph Node. NCI Thesaurus. Code C33659.

Any of the lymph nodes extending from the chin to the occiput, including submental,

submandibular, buccal, mandibular, preauricular, and occipital nodes. 